\title{
Morphobiochemical Variability and Selection Strategies for the Germplasm of Dactylorhiza hatagirea (D. Don) Soo: An Endangered Medicinal Orchid
}

\author{
R. S. Chauhan, ${ }^{1,2}$ M. C. Nautiyal, ${ }^{1}$ R. K. Vashistha, ${ }^{1}$ and P. Prasad ${ }^{1}$ \\ ${ }^{1}$ High Altitude Plant Physiology Research Center, HNB Garhwal University, Srinagar, Uttarakhand 246 174, India \\ ${ }^{2}$ Veer Chandra Singh Garhwali (VCSG) College of Horticulture, UUHF, Bharsar Campus, Pauri, Uttarakhand 246 123, India \\ Correspondence should be addressed to R. S. Chauhan; rchauhanua@gmail.com
}

Received 6 August 2013; Revised 19 November 2013; Accepted 25 November 2013; Published 5 January 2014

Academic Editor: Curtis C. Daehler

Copyright (C) 2014 R. S. Chauhan et al. This is an open access article distributed under the Creative Commons Attribution License, which permits unrestricted use, distribution, and reproduction in any medium, provided the original work is properly cited.

Dactylorhiza hatagirea (D. Don) Soo (Orchidaceae) is an important endangered medicinal herb, distributed in subalpine to alpine regions of the Himalayas. Its tubers are important constituents of many medicines and health tonics. Overexploitation for medicinal uses has decreased availability in natural habitats and this species has been enlisted as endangered, making conservation and cultivation studies necessary. Variability studies may serve as an important tool for effective conservation and for a crop improvement program. Therefore, natural populations of $D$. hatagirea were analyzed for variability on the basis of morphological, biochemical, and isoenzyme patterns. The studied populations were grouped into two clusters. Existing variability among different populations opens up new areas for conservation and perspectives for a genetic improvement program for D. hatagirea.

\section{Introduction}

The genus Dactylorhiza (Orchidaceae) is represented by approximately 75 species, distributed in most parts of Northern temperate zone. Dactylorhiza hatagirea (D. Don) Soo is a perennial orchid, native to the Himalayan region [1]. This species is distributed in India, Pakistan, Afghanistan, Nepal, Tibet, and Bhutan. In India, it is distributed in Jammu and Kashmir [2], Uttarakhand [3-5], and Himachal Pradesh [6]. Tubers of this species are supposed as a potent medicine in Leucorrhea in Traditional System of Medicine (TSM) rich source of mucilage and are used to make Salep, as food and medicine [7], useful as expectorant and astringent [8]. Recently herbal health beverages have also been developed from this species [9]. The species has been categorized as endangered [10], due to overexploitation of tubers for medicinal value, habitat degradations, and other biotic interferences in its distribution ranges. The market demand of this species is increasing while supply is gradually decreasing [11] that call for conservation as well as cultivation.

Effective conservation, management, and recovery of rare and endangered species can be achieved through variability analysis. Variations in morphological appearance among the members of a species become important to the biologist solely because they indicate the presence or absence of physiological attributes that are of ecological significance. Statistical methods including principle components or cluster analysis can be used as useful tools for screening of such populations [12]. Adequate information is available on the distribution pattern $[4,5]$, medicinal properties [7-9] and propagation methods [13] of $D$. hatagirea but there is a lack of knowledge about morphological, biochemical and genetic variability. In view of above, present paper is focused on detail investigation on morpho-biochemical variability among different populations of $D$. hatagirea. Such studies will be helpful for effective conservation management and genetic improvement of $D$. hatagirea.

\section{Materials and Methods}

Field survey was conducted in several parts of Uttarakhand, India known for occurrence of $D$. hatageria, and nine different populations were selected for detail investigations. 


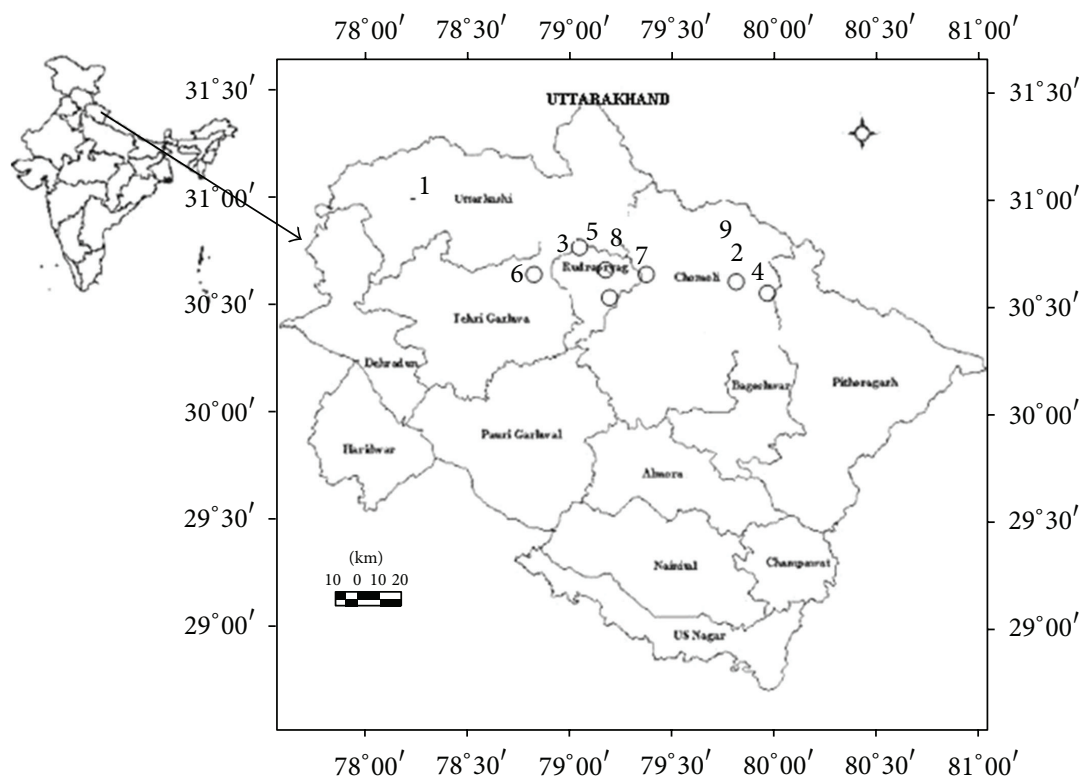

Figure 1: Map showing locations of selected sites of D. hatagirea (1: DH1, 2: DH2, 3- DH3, 4: DH4, 5: DH5, 6: DH6, 7: DH7, 8: DH8, 9: DH9).

TABLE 1: General characteristic of selected natural habitats of $D$. hatagirea.

\begin{tabular}{lccccc}
\hline Study sites & Code & Distribution range $(\mathrm{msl})$ & Habitat & Latitude & Longitude \\
\hline Dayara (Uttarkashi) & DH1 & $3000-3400$ & Open meadow & $30^{\circ} 50^{\prime} \mathrm{N}$ & $78^{\circ} 33^{\prime} \mathrm{E}$ \\
Dronagiri (Chamoli) & DH2 & $3200-3500$ & Open meadow & $30^{\circ} 30^{\prime} \mathrm{N}$ & $79^{\circ} 52^{\prime} \mathrm{E}$ \\
Kedarnath (Rudraprayag) & DH3 & $2900-3500$ & Open meadow & $30^{\circ} 44^{\prime} \mathrm{N}$ & $79^{\circ} 03^{\prime} \mathrm{E}$ \\
Kunwari Pass (Chamoli) & DH4 & $3000-3400$ & Open meadow & $30^{\circ} 07^{\prime} \mathrm{N}$ & $79^{\circ} 58^{\prime} \mathrm{E}$ \\
Madhyameshwar (Rudraprayag) & DH5 & $3500-3800$ & Open meadow & $30^{\circ} 39^{\prime} \mathrm{N}$ & $79^{\circ} 14^{\prime} \mathrm{E}$ \\
Panwalikantha (Tehri) & DH6 & $3300-3500$ & Open meadow & $30^{\circ} 34^{\prime} \mathrm{N}$ & $78^{\circ} 52^{\prime} \mathrm{E}$ \\
Rudranath (Chamoli) & DH7 & $3000-3200$ & Open meadow & $30^{\circ} 11^{\prime} \mathrm{N}$ & $79^{\circ} 28^{\prime} \mathrm{E}$ \\
Tungnath (Rudraprayag) & DH8 & $3200-3600$ & Open meadow & $30^{\circ} 14^{\prime} \mathrm{N}$ & $79^{\circ} 22^{\prime} \mathrm{E}$ \\
The Valley of Flowers (Chamoli) & DH9 & $3000-4200$ & Open meadow & $30^{\circ} 10^{\prime} \mathrm{N}$ & $79^{\circ} 57^{\prime} \mathrm{E}$ \\
\hline
\end{tabular}

A detailed description of selected study sites is presented (Figure 1, Table 1). Considering endangered status of the species in Uttarakhand [10], experiments were designed in such a way that minimum number of samples may provide optimum information. Ten mature plants from each study site were sampled randomly for morphological details (plant height, number of flower/plant, inflorescence length, and economic yield) during the month of September. These plants were dug out for the estimation of economic yield (tubers). The tubers were separated, washed with running water, and dried at $40^{\circ} \mathrm{C}$ temperature until constant weight. One set of fresh tubers was immediately crushed in liquid nitrogen to seize enzymatic activities and then stored at $\left(-80^{\circ} \mathrm{C}\right)$ in a deep freezer until analysis.

These samples were used to estimate variations in soluble sugars, protein content, and isoenzymes. Soluble sugar content was estimated using the Anthrone method [14] and soluble protein content was determined using the Bradford method [15]. The absorbance of the reaction mixture was read in a spectrophotometer (Beckman DU-640). Isoenzyme variation was analyzed on $10 \%$ polyacrylamide slab gels in a discontinuous gel electrophoretic system at a constant current of $20 \mathrm{~mA}$ [16]. Esterase (EC 3.1.1.1) and peroxidase (EC 3.4.11) isoenzymes were detected in gels using the methods of Bhadula and Sawhney [17] and Welter [18], respectively, among different populations. Collected data were subjected to analysis of variance (ANOVA) and only significant variations were used for multivariate analysis of Mahalanobis distance [19]. The analysis was performed using indostat statistical package (http://www.windostat.org) and the cluster formation was confirmed by the Tocher method [20].

\section{Results}

The germplasm collected from different populations showed considerable variation in plant height, number of flowers, length of inflorescence, economic yield, and biochemical parameters (Table 2). The variability range was between 13.2 and $54.3 \mathrm{~cm}$ in plant height, 14.9 and 29.4 in number of flowers per plant, 3.9 and $11.7 \mathrm{~cm}$ in inflorescence length, and 
TABLE 2: Mean growth performance of $D$. hatagirea at different natural populations.

\begin{tabular}{|c|c|c|c|c|c|c|c|}
\hline Study sites & $\begin{array}{c}\begin{array}{c}\text { Economic yield } \\
(\mathrm{g} / \text { plant })\end{array} \\
\end{array}$ & $\begin{array}{c}\text { Plant height } \\
(\mathrm{cm})\end{array}$ & $\begin{array}{c}\text { Number of } \\
\text { flowers/plants }\end{array}$ & $\begin{array}{c}\text { Length of } \\
\text { Inflorescence }(\mathrm{cm})\end{array}$ & $\begin{array}{c}\text { Soluble sugar } \\
(\mathrm{mg} / \mathrm{g})\end{array}$ & $\begin{array}{l}\text { Starch } \\
(\mathrm{mg} / \mathrm{g})\end{array}$ & $\begin{array}{c}\text { Soluble } \\
\text { protein }(\mathrm{mg} / \mathrm{g})\end{array}$ \\
\hline $\mathrm{DH} 1$ & 0.5 & 45.0 & 22.0 & 10.8 & 20.6 & 45.6 & 10.6 \\
\hline DH2 & 0.6 & 35.5 & 22.3 & 10.0 & 34.0 & 54.8 & 26.8 \\
\hline DH3 & 0.7 & 13.8 & 14.9 & 3.9 & 34.5 & 57.1 & 11.5 \\
\hline DH4 & 0.5 & 13.2 & 24.5 & 6.5 & 35.6 & 56.0 & 10.4 \\
\hline DH5 & 0.6 & 37.2 & 26.5 & 9.5 & 28.0 & 59.1 & 14.3 \\
\hline DH6 & 0.5 & 54.3 & 26.6 & 9.6 & 33.5 & 57.0 & 11.8 \\
\hline DH7 & 0.5 & 51.3 & 29.4 & 11.7 & 40.7 & 68.1 & 10.4 \\
\hline DH8 & 0.4 & 41.0 & 23.4 & 10.7 & 21.7 & 53.2 & 15.6 \\
\hline DH9 & 0.4 & 29.0 & 22.0 & 5.7 & 23.0 & 74.3 & 26.9 \\
\hline Mean & 0.5 & 35.6 & 23.5 & 8.6 & 30.2 & 58.4 & 15.4 \\
\hline $\mathrm{SD}^{*}$ & 0.1 & 14.6 & 4.1 & 2.6 & 7.1 & 8.4 & 6.8 \\
\hline Range & $0.4-0.7$ & $13.2-54.3$ & $14.9-29.4$ & $3.9-11.7$ & $20.6-40.7$ & $45.6-74.3$ & $10.4-26.9$ \\
\hline CD 5\% ${ }^{* *}$ & 0.18 & 9.99 & 5.72 & 4.73 & 9.58 & 8.55 & 4.87 \\
\hline
\end{tabular}

*SD: standard deviation; ${ }^{* *} \mathrm{CD}$ : critical difference.

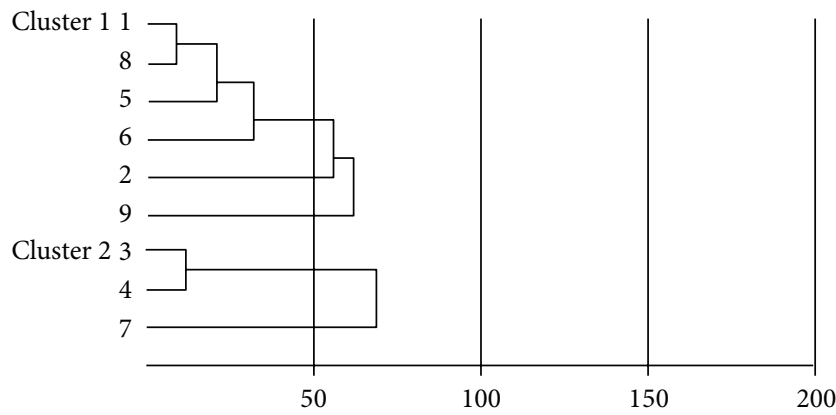

Figure 2: Dendrogram of $D$. hatagira by Tocher method (1: DH1, 2: DH2, 3: DH3, 4: DH4, 5: DH5, 6: DH6, 7: DH7, and 8: DH8, 9: DH9).

0.4 and $0.7 \mathrm{~g}$ per plant in economic yield. Biochemical parameters also showed great variability among studied populations. The variability range was between 20.6 and $40.7 \mathrm{mg} / \mathrm{g}$ in soluble sugar, 45.6 and $74.3 \mathrm{mg} / \mathrm{g}$ in starch, and 10.4 and $26.9 \mathrm{mg} / \mathrm{g}$ in soluble protein content. Such variations could be due to edaphic, microclimate, environmental factors, and so forth. In view of considerable amount of variability, $D^{2}$ values were compared for all possible pairs of populations. Based on $D^{2}$ values these populations could be grouped into two clusters (Figure 2). The higher contribution of characters regarding variability was shown by soluble protein (72.22\%), plant height $(13.89 \%)$, and starch content $(8.33 \%)$, whereas other quantitative characters, that is, number of flowers and soluble sugar showed similar share of $2.78 \%$. Mean growth performance of both clusters is presented separately in Table 3. Cluster one contains maximum 6 populations, that is, DH1, DH8, DH5, DH6, DH2, and DH9, whereas cluster two contains 3 population $\mathrm{DH} 3, \mathrm{DH} 4$, and $\mathrm{DH} 7$. The average intracluster distance ranged from 7 to 8 whereas the intercluster distance ranged from 8 to 13 (Table 4).

There were significant differences among the parameters measured, indicating variability among the populations
(Figure 3(a)). Total number, intensity, and position of bands varied from population to population. DH8 and DH4 populations emerged as a distinct cluster by showing specific banding pattern of esterase isoenzyme as compared to the rest of the populations. These two populations showed more compact and dark stained band. The peroxidase pattern in $\mathrm{DH} 3$ and DH7 populations emerged as a distinct clusture by showing specific banding pattern. Intensity of bands was very dark in DH3 followed by DH7 populations, whereas bands of light intensity were resolved in $\mathrm{DH} 1$ and $\mathrm{DH} 2$ population (Figure 3(b)).

\section{Discussion}

Germplasm of $D$. hatageria collected from different geographical locations of the Garhwal Himalaya was grouped into two clusters based on their similarities and variations. They varied considerably in the morphology, biochemical parameters, and isoenzyme pattern. Over the long term, the ability of a population to respond adaptively to environmental changes depends on the level of genetic variability or diversity it contains [21]. Variations in plant height were related to the soil and climatic factors [22]. Variation in the morphological characters is possible due to variation in topography, elevation, soil, rainfall, and other climatic conditions, peculiar to Himalaya [23]. In addition, available soil nutrient level also plays an important role in determining morphological variations in plants [24,25] and climatic factors can be considered as indicators to alter assimilate investment pattern [26].

Biochemical variations suggested polymorphic nature of the species and it is argued that they can be used as an indicators to the impact of microclimatic conditions on plant life [25] and therefore, reflects an adaptive feature of the species [27]. Morphological variability in plants and differences in protein and sugar levels were important parameters to study natural populations of rare plants; these 
TABLE 3: Cluster mean of seven characters of $D$. hatagirea.

\begin{tabular}{lcccccccc}
\hline Clusters & $\begin{array}{c}\text { Number of } \\
\text { locations }\end{array}$ & $\begin{array}{c}\text { Economic yield } \\
(\mathrm{g} / \text { plant })\end{array}$ & $\begin{array}{c}\text { Plant height } \\
(\mathrm{cm})\end{array}$ & $\begin{array}{c}\text { Number of } \\
\text { flowers/plant }\end{array}$ & $\begin{array}{c}\text { Inflorescence } \\
\text { length }(\mathrm{cm})\end{array}$ & $\begin{array}{c}\text { Soluble sugar } \\
(\mathrm{mg} / \mathrm{g})\end{array}$ & $\begin{array}{c}\text { Starch } \\
(\mathrm{mg} / \mathrm{g})\end{array}$ & $\begin{array}{c}\text { Soluble } \\
\text { protein }(\mathrm{mg} / \mathrm{g})\end{array}$ \\
\hline 1 & 6 & 0.5 & 40.32 & 23.81 & 9.27 & 26.8 & 57.31 & 17.66 \\
2 & 3 & 0.55 & 26.09 & 22.91 & 7.37 & 36.94 & 60.4 & 10.78 \\
\hline
\end{tabular}

TABLE 4: Intra- and intercluster divergence $\left(D^{2}\right)$ among three clusters of $D$. hatagirea.

\begin{tabular}{lcc}
\hline Clusters & 1 & 2 \\
\hline 1 & 7.52 & 13.40 \\
& & 8.51 \\
\hline
\end{tabular}

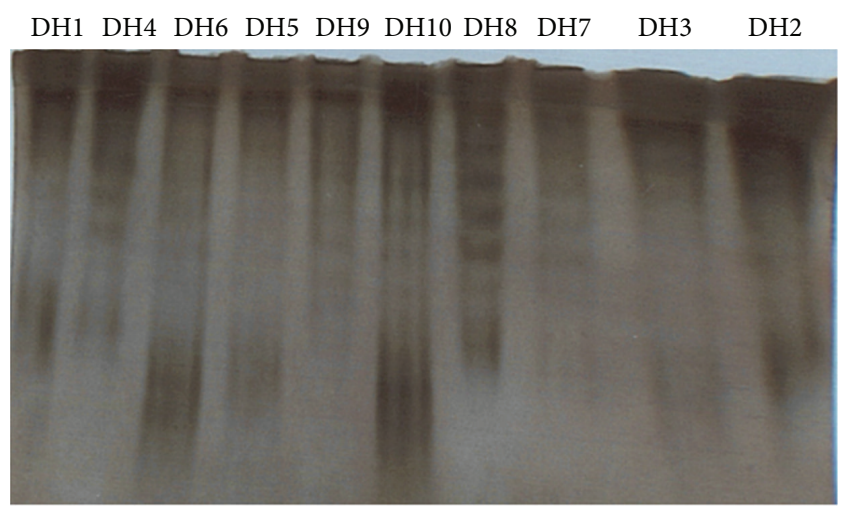

(a)

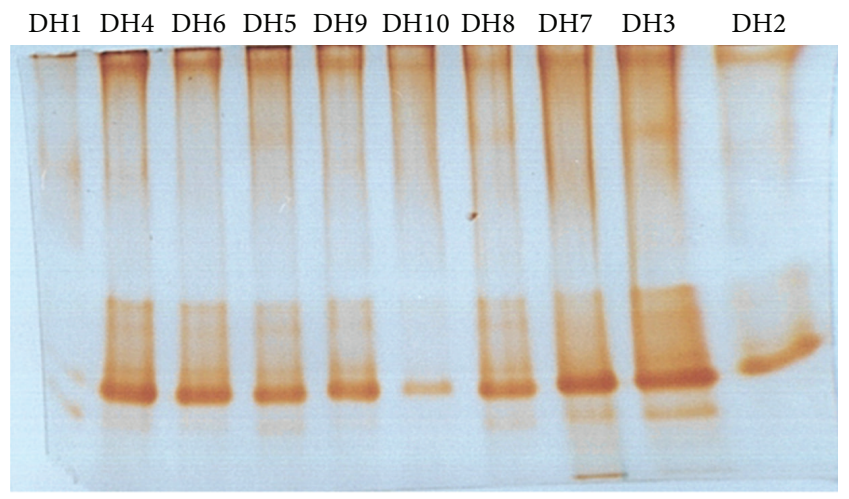

(b)

FIGURE 3: Heterozygosity in isoenzyme banding pattern. (a) Esterase and (b) peroxidase among ten different populations of $D$. hatagirea.

parameters also reflect a variation due to environmental conditions. Average economic yield in $\mathrm{DH} 2$ population is positively correlated with the number of flowers, soluble sugar, starch, and soluble protein content. Such information on morphometric, primary metabolites and isoenzyme pattern suggests that secondary metabolites may also vary in these populations. Increase in primary metabolites showed significant increase in active constituents in adantoid ferns [28]. Isoenzyme studies also supported variability among studied populations. Germplasm diversity based on standard morphological marker has proved to be inadequate because of wide spectrum of phenotypic variation and their interaction with environment [29], whereas esterase isoenzyme is an excellent marker in variability studies which indicates intrapopulation variations [30].

\section{Conclusions}

This study revealed significant differences among the parameters measured, indicating variability among these populations. Variability existing among different populations opens a new area for conservation and genetic improvement of $D$. hatagirea. These variations may be used as markers for crop improvement program. DH2 (Dronagiri) population showed better performance among the studied populations, which can be used as elite germplasm source for multiplication of $D$. hatagirea. On the basis of such multifaceted information on specific species, future conservation strategies and cultivation of wild medicinal species can be initiated [31].

\section{Conflict of Interests}

The authors declare that there is no conflict of interests regarding the publication of this paper.

\section{Acknowledgments}

The authors are thankful to Dr. H. Purohit (SRF), HAPPRC, Srinagar, for helping in this work. Financial support from Department of Biotechnology, Government of India, New Delhi, is gratefully acknowledged.

\section{References}

[1] H. K. Badola and S. Aitken, "The Himalayas of India: a treasury of medicinal plants under siege," Biodiversity, vol. 4, pp. 3-13, 2003.

[2] U. Dhar and P. Kachroo, Alpine Flora of Kashmir Himalaya, Scientific Publishers, Jodhpur, India, 1983.

[3] P. K. Hajra and B. Badoni, Plant Wealth of Nanda Devi Biosphere Reserve, Botanical Survey of India, Calcutta, India, 1995.

[4] A. Bhatt, S. K. Joshi, and S. Gairola, "Dactylorhiza hatagirea (D. Don) Soo-a west Himalayan orchid in peril," Current Science, vol. 89, no. 4, pp. 610-612, 2005.

[5] R. S. Chauhan and M. C. Nautiyal, "A note on Dactylorhiza hatagirea (D. Don) Soo," The McAllen International Orchid Society Journal, vol. 9, no. 2, pp. 8-12, 2008.

[6] B. S. Aswal and B. N. Mehrotra, Flora of Lahaul-Spiti, Bishen Singh and Mahendra Pal Singh, Dehradun, India, 1994.

[7] CSIR, The Wealth of India, vol. 10 of Publication and Information Directorate, Council of Scientific and Industrial Research, New Delhi, India, 1976. 
[8] K. R. Kirtikar and B. D. Basu, Indian Medicinal Plants, Bishen Singh Mahendra Pal Singh, Dehradun, India, 1989.

[9] B. Ballabh, O. P. Chaurasia, and Z. Ahmed, "Herbal products from high altitude plants of Ladakh Himalaya," Current Science, vol. 92, no. 12, pp. 1664-1665, 2007.

[10] Anon, Conservation Assessment and Management Prioritization for the Medicinal Plants of Jammu and Kashmir, Himachal Pradesh and Uttarakhand, FRLHT, Bangalore, India, 2003.

[11] D. K. Ved and G. S. Goraya, Demand and Supply of Medicinal Plants in India, Bishan Singh Mahendra Pal Singh, Dehradun \& FRLTH, Bangalore, India, 2008.

[12] H. R. Karimi, Z. Zamani, A. Ebadi, and M. R. Fatahi, "Morphological diversity of Pistacia species in Iran," Genetic Resources and Crop Evolution, vol. 56, no. 4, pp. 561-571, 2009.

[13] D. Giri and S. Tamta, "Combined effect of PGRs and soil facilitate early flowering of an endangered alpine orchid Dactylorhiza hatagirea at lower elevation," Current Science, vol. 99, no. 1, pp. 21-23, 2010.

[14] R. M. McCready, J. Guggolz, V. Silviera, and H. S. Owens, "Determination of starch and amylose in vegetables: application to peas," Analytical Chemistry, vol. 22, no. 9, pp. 1156-1158, 1950.

[15] M. M. Bradford, "A rapid and sensitive method for the quantitation of microgram quantities of protein utilizing the principle of protein dye binding," Analytical Biochemistry, vol. 72, no. 1-2, pp. 248-254, 1976.

[16] B. J. Davis, "Disc electrophoresis. II. Method and application to human serum proteins," Annals of the New York Academy of Sciences, vol. 121, pp. 404-427, 1964.

[17] S. K. Bhadula and V. K. Sawhney, "Esterase activity and isozymes during the ontogeny of stamens of male fertile Lycopersicon esculentum mill., a male sterile stamenless- 2 mutant and the low temperature-reverted mutant," Plant Science, vol. 52, no. 3, pp. 187-194, 1987.

[18] L. R. Welter, "Isoenzyme analysis of cultured plant cells," in Plant Tissue Culture Methods, L. R. Welter and F. Constabel, Eds., pp. 105-111, National Research Council of Canada, Saskatoon, Canada, 1982.

[19] P. C. Mahalanobis, "On the generalized distance in statistics," Proceedings of the National Institute of Science, vol. 2, pp. 49-55, 1936.

[20] C. R. Rao, Advanced Statistical Methods in Biomedical Research, John Wiley \& Sons, New York, NY, USA, 1952.

[21] F. J. Ayala and J. A. Kiger, Modern Genetics, Benjamin/Cummings, Menlo Park, Calif, USA, 2nd edition, 1984.

[22] N. Krishnan, A. Jeyachandran, and N. Nagendran, "Effect of seasonal and altitudinal variations on growth performance of Acalypha indica Linn. in Alagar Hill (Eastern Ghats), South India," Tropical Ecology, vol. 41, no. 1, pp. 41-45, 2000.

[23] R. D. Gaur, D. S. Rawat, and L. R. Dangwal, "A contribution to the flora of Kunwari Pass-Dalisera alpine zone in Garhwal Himalaya," Journal of Economic and Taxonomic Botany, vol. 19, pp. 9-26, 1995.

[24] M. Pigliucci, P. Diiorio, and C. D. Schlichting, "Phenotypic plasticity of growth trajectories in two species of Lobelia in response to nutrient availability," Journal of Ecology, vol. 85, no. 3, pp. 265-276, 1997.

[25] C. P. Kuniyal, S. K. Bhadula, and P. Prasad, "Morphological and biochemical variations among the natural populations of Aconitum atrox (Bruhl) Muk. (Ranunculaceae)," Journal of Plant Biology, vol. 29, no. 1, pp. 91-96, 2002.
[26] C. Korner and S. P. Menendez-Riedl, "The significance of developmental aspects in plant growth analysis," in Causes and Consequences of Variation in Growth Rate and Productivity of Higher Plants, H. Lambers, Ed., pp. 141-157, Academic Publishers, The Hague, The Netherlands, 1989.

[27] S. K. Bhadula, A. P. Thapliyal, and A. N. Purohit, "Seed protein, esterase and acid phosphatase in Rhododendron species from different altitudes in Garhwal Himalaya," Indian Journal of Experimental Biology, vol. 19, pp. 199-200, 1981.

[28] P. Guha, K. Gupta, and R. Mukhopadhyay, "Impact of seasons on some biochemical parameters in three adantoid ferns," Indian Journal of Plant Physiology, vol. 11, pp. 152-159, 2006.

[29] L. Mannetji, "Considerations on the taxonomy of the genus Stylosanthes," in The Biology and Agronomy of Stylosanthes, H. M. Stace and L. A. Edye, Eds., Academic Press, Sydney, Australia, 1984.

[30] S. K. Bhadula, A. Singh, H. Lata, C. P. Kuniyal, and A. N. Purohit, "Genetic resources of Podophyllum hexandrum Royle, an endangered medicinal species from Garhwal Himalaya, India," Plant Genetic Resources Newsletter, vol. 106, pp. 26-29, 1996.

[31] S. Airi, R. S. Rawal, U. Dhar, and A. N. Purohit, "Assessment of availability and habitat preference of Jatamansi-a critically endangered medicinal plant of west Himalaya," Current Science, vol. 79, no. 10, pp. 1467-1471, 2000. 

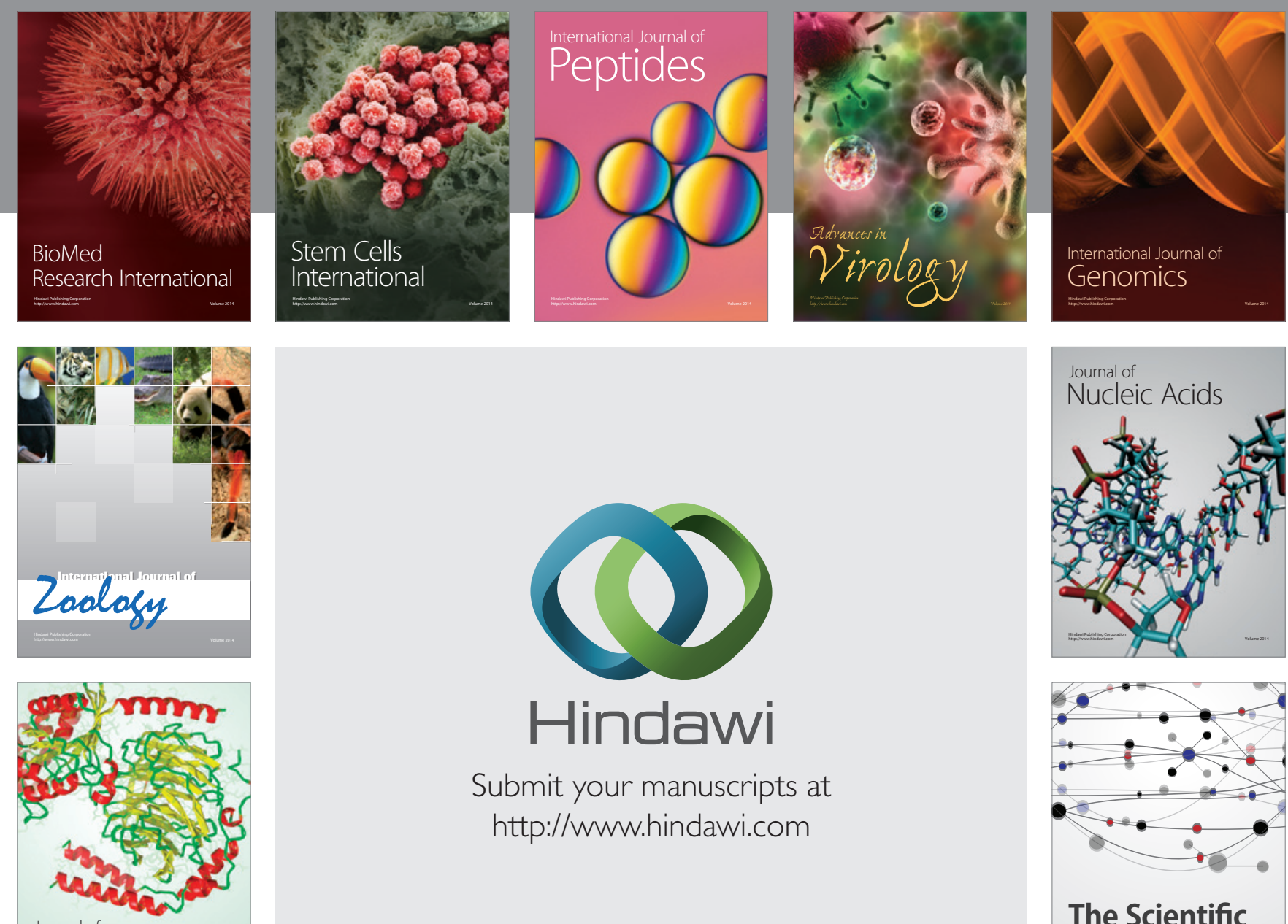

Submit your manuscripts at

http://www.hindawi.com

Journal of
Signal Transduction
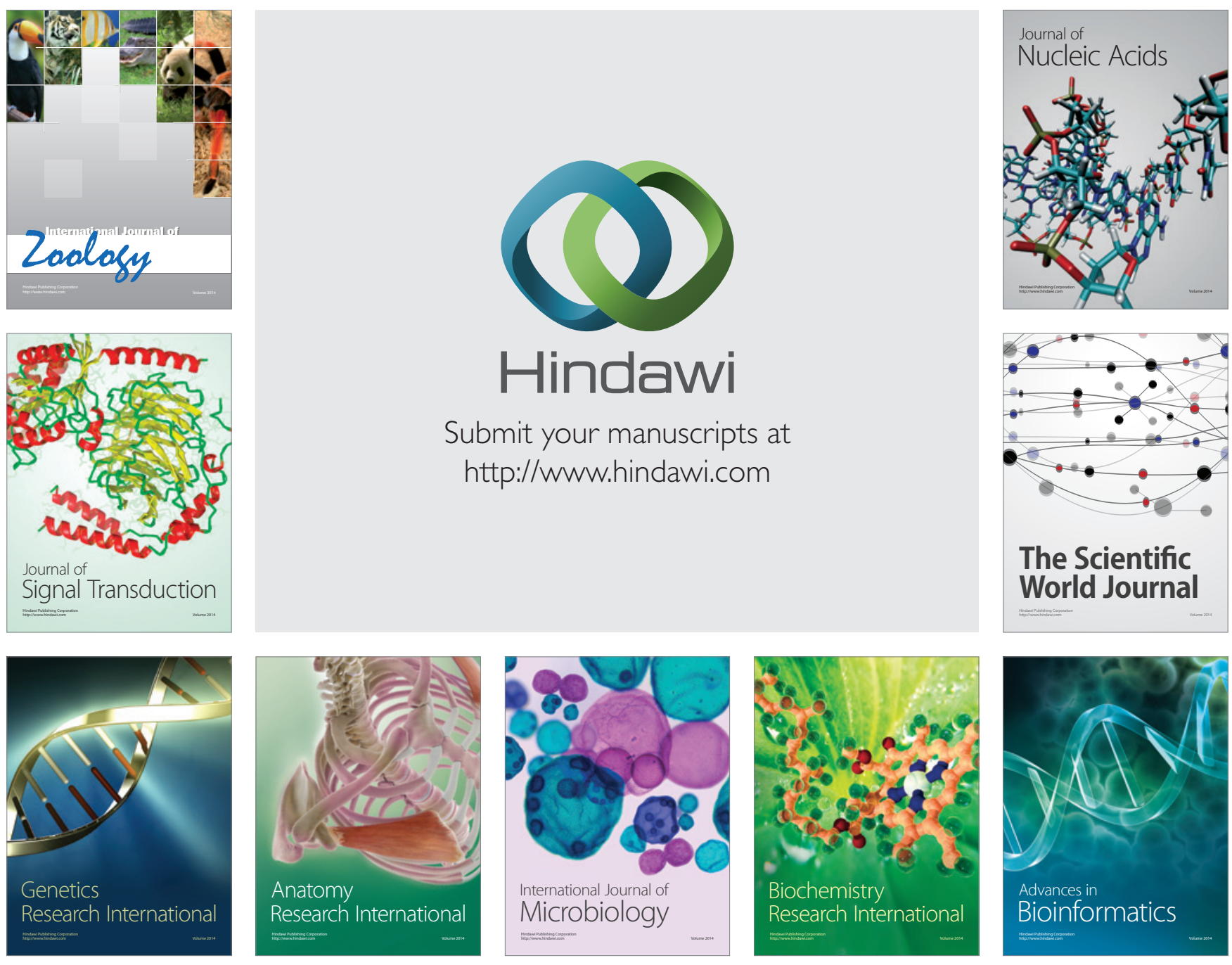

The Scientific World Journal
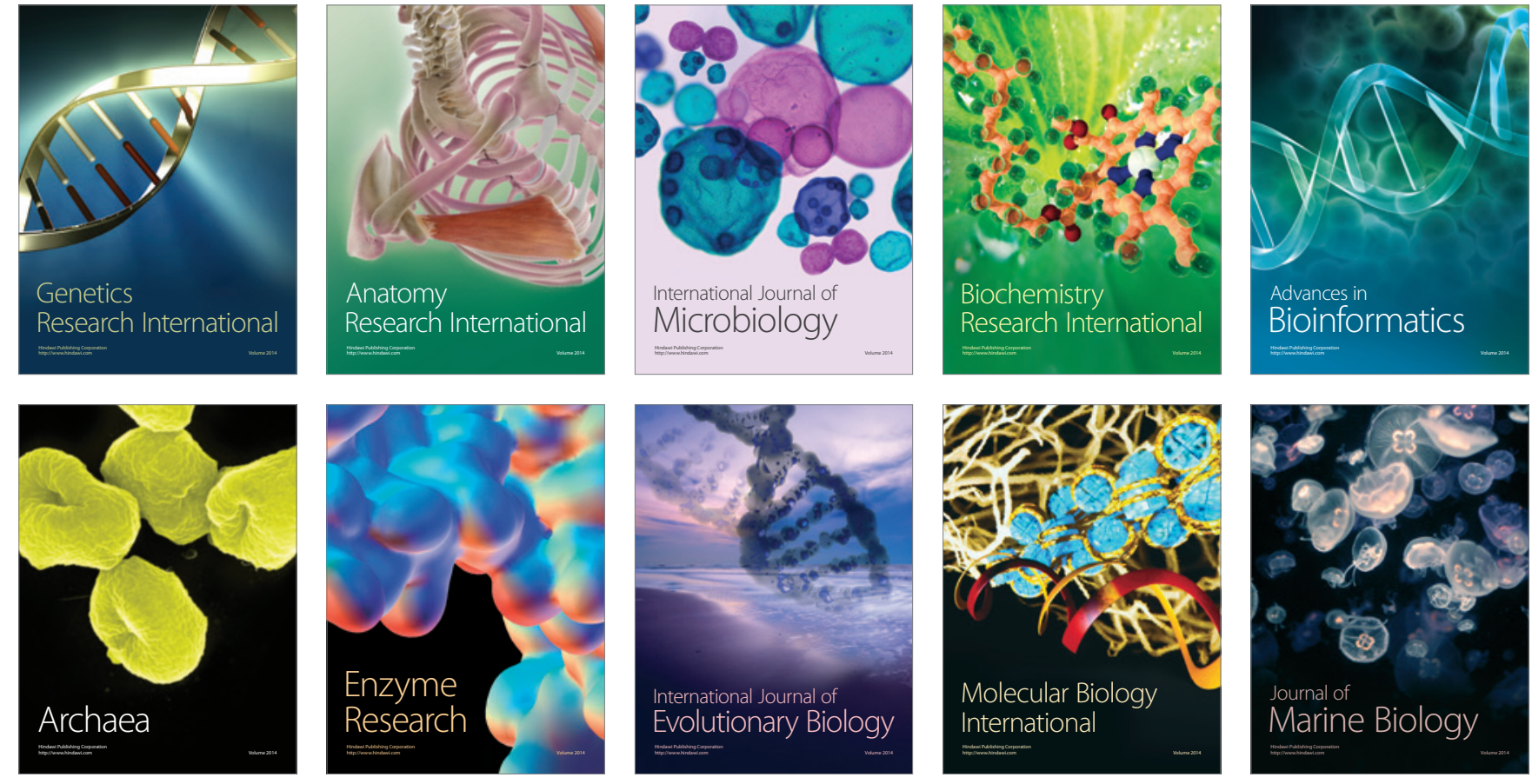